\title{
Radiolarian researchers based in Italy during the late nineteenth and early twentieth centuries
}

\author{
GIUSEPPE CORTESE \\ GNS Science, PO Box 30368, Lower Hutt 5040, New Zealand \\ (e-mail: g.cortese@gns.cri.nz)
}

\begin{abstract}
In the second half of the nineteenth century a few Italian radiolarists, including Dante Pantanelli and Senofonte Squinabol, made substantial contributions to the taxonomic study of radiolarians and their utilization in dating Mesozoic rocks. This time interval was very important in the history of science in general, and biology in particular, with numerous scientific expeditions collecting a wealth of biological and sedimentary material from the oceans that took decades to be described and analysed. One of the most famous examples is the Report of the Challenger Expedition, which included a thorough study of radiolarians by Ernst Haeckel which became the basis of radiolarian classification. Haeckel was one of the foremost promoters of the largest cultural revolution of his epoch: Darwinism. He, together with a long list of eminent scientists, used comparative anatomy and embryology to provide evidence of the theory of evolution through natural selection. One of his students, Anton Dohrn, also a fervent Darwinist, founded one of the oldest independent marine biology stations in the world: the Statione Zoologica in Naples. It was here that at the beginning of the twentieth century another eminent Italian radiolarist, Paolo Enriques, worked for many years to revise and improve Haeckel's classification scheme of radiolarians, although he died before it was completed or published. J. Micropalaeontol. 33(1): 95-103, January 2014.
\end{abstract}

KEYWORDS: Radiolaria, biological stations, Darwinism, history of science, evolution

\section{FIRST RADIOLARIAN RESEARCHERS IN ITALY}

During the eighteenth and early nineteenth centuries, research in the field of radiolarian micropaleontology and biology was almost exclusively the domain of German scientists, e.g. Meyen, Ehrenberg, Rüst, Haeckel, Stöhr and many others (for details on early German workers, see Lazarus 2014). The most important date in radiolarian studies is connected to one of these early workers, to the monumental monograph published by Haeckel in 1887 . This publication, together with a related work (Haeckel, 1881), introduced over 1200 genera and 2800 species of living and fossil radiolarians. The material for Haeckel's study was collected during the HMS Challenger Expedition (1873-1876), which sailed around the globe for 70000 nautical miles surveying, exploring and collecting samples from the oceans and their floors. A series of such natural science expeditions around the world resulted in the birth of several disciplines in oceanography and biology, and had set the scene for the formulation (and later the search for evidence in favour) of Darwin's evolutionary theory. Ernst Haeckel, arguably the most important early radiolarian worker, had strong connections to Italy in his early researches. In fact, his first major work on radiolarians was based on material collected during a six-month study of marine plankton in the Strait of Messina (Haeckel, 1860). It is at this time that Italian scientists started to make important contributions to the study of radiolarians. Their names will be familiar to Mesozoic workers in this field, as they described a large number of taxa, and had several genera and species named after them. A few examples of the latter include: Pantanellium squinaboli, Homoeoparonaella sp., Squinabolella sp. and Archaeodictyomitra squinaboli. Most of these early researchers were quite eclectic figures, and their scientific interests were not limited to radiolarians, but extended to many other fossil groups. Several of the Italian palaeontologists/geologists presented below (particularly Pantanelli) had very strong interests and skills in malacology, and can be considered mainly as experts in that discipline.
Dante Pantanelli (Siena, 1844-Modena, 1913)

Pantanelli (Fig. 1) graduated in mathematics at Pisa University in 1865 , and went on to teach physics at high school level from 1865 (Cagliari) to 1882 (Siena). During his stay in Siena, he started to devote himself to natural sciences and particularly malacology, palaeontology and geology. In doing so, he developed such a scientific expertise that in 1882 he managed to obtain a chair as Professor of Geology and Mineralogy at the University of Modena. Haeckel mentions Pantanelli in his Challenger report, noting that the Italian radiolarist was studying the Diaspri Toscani Formation in Tuscany, albeit wrongly assigning it to the Eocene (Pantanelli, 1880).

\section{Senofonte Squinabol (?, 1861-Torino, 1941)}

Squinabol was Professor of Geology and Palaeontology at both Padua and Torino universities (Fig. 2). His name, at least in the radiolarian community, is linked to his pioneering efforts in dating Mesozoic sequences in Italy, as he was the first to propose a Jurassic age for radiolarites based on radiolarians. He described a total of 246 Mesozoic radiolarian species, mostly in a series of four papers (Squinabol, 1903, 1904, 1912, 1914), and was second only to Rüst for the number of species described between 1867 and 1959 (O’Dogherty et al., 2009) (Fig. 5). He was also instrumental in providing a colleague of his at the University of Torino (anthropologist Giovanni Marro) with location information, allowing the latter to discover the Valcamonica rock carvings. These are an enormous collection of Stone Age petroglyphs that much later (1979) became the first World Heritage Site recognized by UNESCO in Italy.

\section{Carlo Fabrizio Parona (Melegnano, Milano, 1855-Busto Arsizio, 1939)}

Parona was a contemporary of Squinabol, and he also taught geology at the University of Torino, from 1889 to 1930 . He was a geologist and palaeontologist, President of the Torino Academy of 


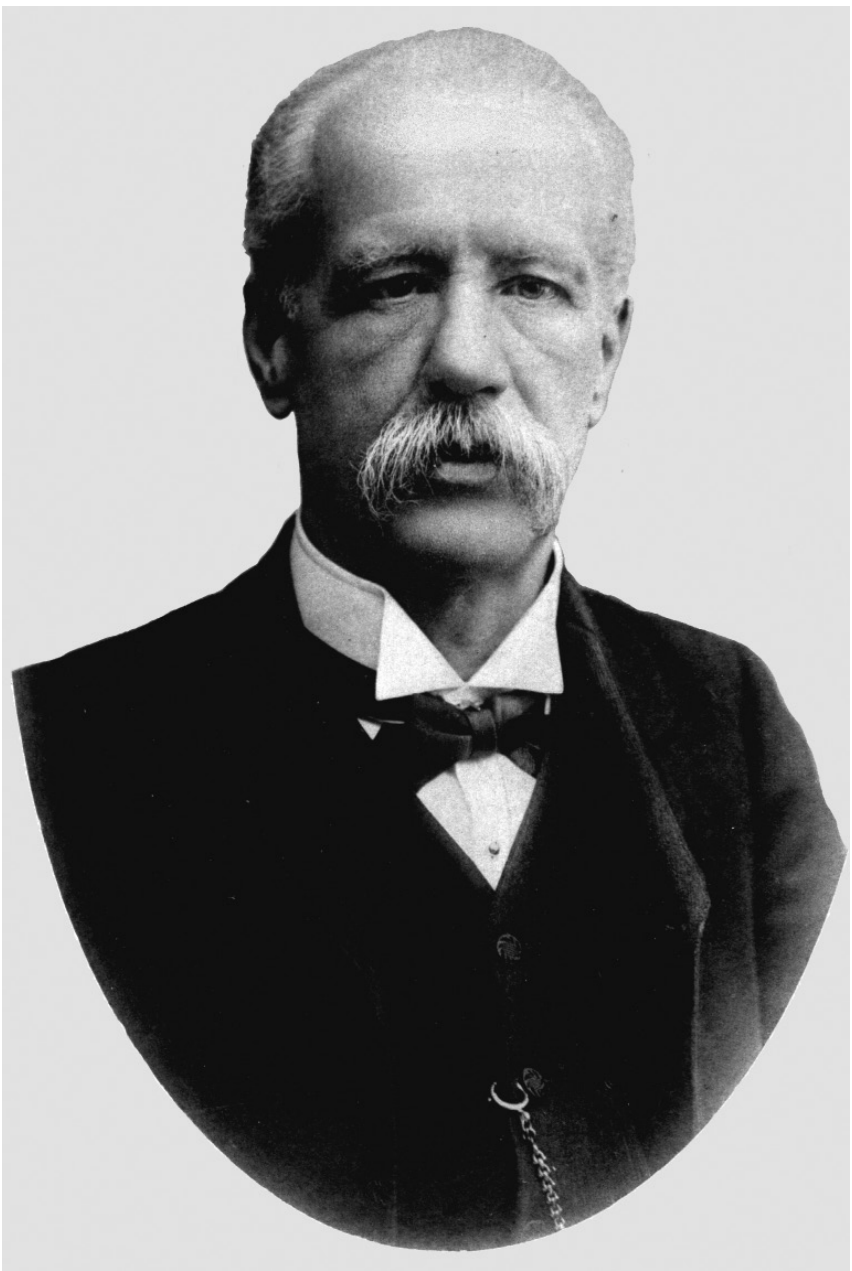

Fig. 1. Portrait of Dante Pantanelli. Image courtesy of Bolletino della Società Geologica Italiana.

Sciences, and shared with Squinabol his special interest in Mesozoic formations of northern Italy. His scientific work was centred on palaeontology and stratigraphy, particularly of the alpine regions of Italy.

\section{Paolo Vinassa de Regny (Florence, 1871-Cave di Lavagna, 1957)}

Vinassa de Regny was another geologist and palaeontologist of extremely broad talent and culture. He wrote over 300 publications, was a university professor, explorer, geographer and senator (1934-1957). As a private pastime from all these roles, he was very well versed in Dante Alighieri and, as a result of his longstanding interest and research on the topic, published in 1955 a book on Dante and Pythagoric symbolism, discussing the esoteric significance of numbers in the Divine Comedy (Vinassa de Regny, 1955). He was professor in Bologna (1899-1913, Geology and Paleontology), Perugia (1902-1908, Mineralogy, Lithology, and Agrarian Geology), Catania, Parma and Pavia. He was Dean of the University of Pavia and Director of the Geology section of the Natural History Museum in Pavia (1924-1941). His most commonly cited works on radiolarians (Vinassa de Regny, 1899, 1900, 1901) represent only part of his scientific interests, which ranged from descriptive palaeontology to palaeobiology, stratigraphy, tectonics, geochemistry and applied geology. In the latter discipline he pioneered the field of agrarian geology, writing a treatise on the topic and carrying out studies in the then North African colonies of Italy. He also contributed to the geological surveying of Carnia, founded the Journal of Practical Geology (which later became the Italian Journal of Geology), and was director of the Rivista Italiana di Paleontologia from 1893 to 1942. The only blemish on this otherwise truly remarkable curriculum was his anti-Darwinian view. Vinassa de Regny's somewhat anachronistic opinions on Darwinism are interesting as, a few decades earlier, many eminent researchers including the most famous radiolarist Haeckel were actively trying to ground-truth Darwin's theory.

\section{THE RISE OF OCEANOGRAPHIC RESEARCH AND BIOLOGICAL STATIONS}

Roughly 150 years before Vinassa de Regny was born, another Italian had published the work Histoire physique de la mer (Marsili, 1725), thus founding three major disciplines, as this represents the first work on physical, chemical and biological oceanography. A few decades later, physical and chemical observations of the oceans were in full bloom, with many voyages being organized, many of them having full-time naturalists on board. These expeditions were intended to collect a great variety of data, and brought back many species of plants and animals from around the world. This tradition led to the establishment of marine biology stations. These started to appear in the second half of the nineteenth century, with the first one being the Marine Station of Concarneau (Brittany, France), established in 1859 and run by the Muséum National d'Histoire Naturelle. Other stations followed through the years, among them:

1872: Zoological Station ‘Anton Dohrn' (Naples, Italy)

1872: Roscoff (University of Paris, France)

1881: Watson's Bay Zoological Station (Sydney, Australia)

1886: Villefranche-sur-mer Biological Station (France)

1888: Marine Biological Laboratory at Woods Hole (Massachusetts, USA)

1891: Marine Biology Station (Bergen, Norway)

1892: Hopkins Marine Station, Stanford (California, USA)

1892: Biologische Anstalt Helgoland (Germany)

\section{Darwinism, Haeckel, Anton Dohrn}

The large body of observations collected at these stations helped strengthen the foundations of one of humanity's biggest cultural revolutions: evolutionary theory. The second half of the nineteenth century saw the publication of Darwin's On the Origin of Species (1859), with some very famous physicians of the time (Johannes Mueller, Ernst Haeckel, Hermann von Helmholtz, Karl Gegenbaur) turning their interests to natural science, making substantial contributions to the field. This crossing of paths between medicine and Darwinism was strongly related to Haeckel's recapitulation theory: the idea that an organism during its embryonic development passes through the major stages of the evolutionary past of its species. At that time, therefore, comparative embryology (a major branch of medicine and zoology) was becoming the cornerstone of morphology and evolution, that in turn thus became 


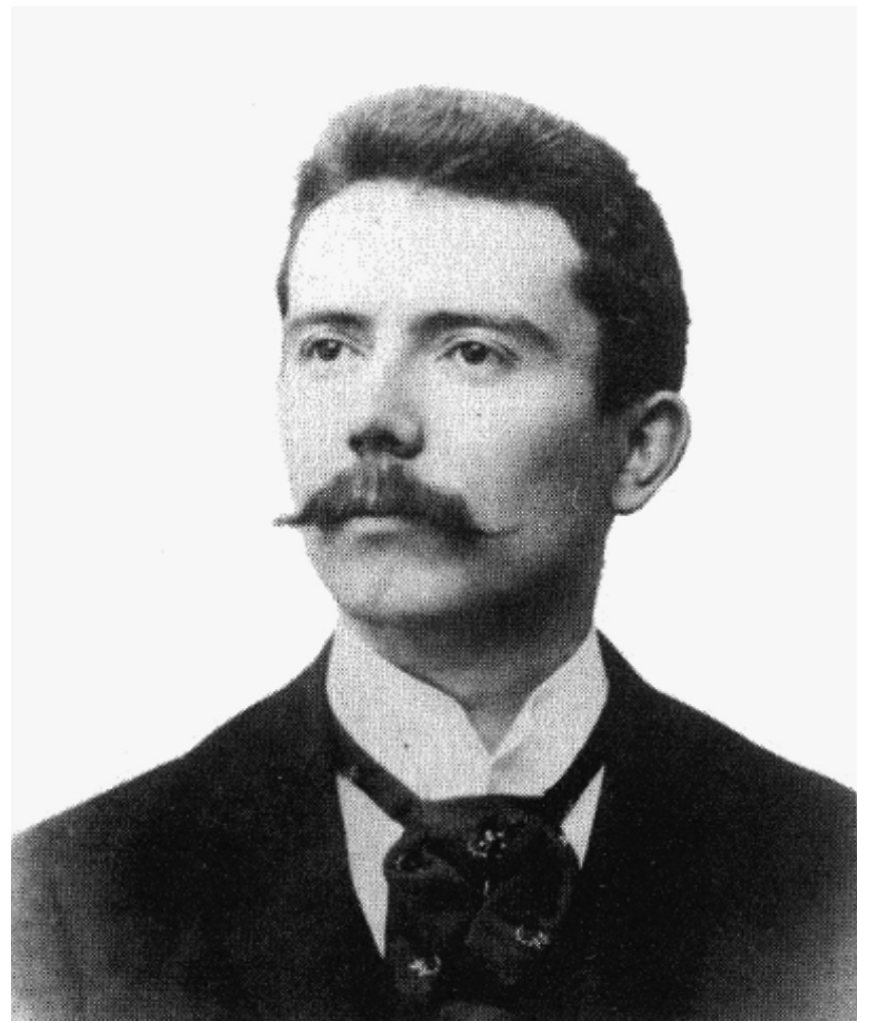

Fig. 2. Portrait of Senofonte Squinabol. Image courtesy of Iginio Dieni, University of Padua.

a major way by which physicians and zoologists sought to expand and develop Darwinian theory over the last 30 years of the nineteenth century.

Ernst Haeckel (1834-1919), possibly the most influential radiolarist of all time, became Professor of Zoology at the University of Jena in 1865, where he passed his passion for Darwinism to one of his students: Felix Anton Dohrn (18401909). During 1865, immediately after having obtained his $\mathrm{PhD}$ from the University of Breslau, Dohrn was collecting plankton samples in Helgoland together with Haeckel (Fig. 3), and first had the idea of building a zoological station (Groeben, 2006). In 1869 , Dohrn was again collecting plankton, this time in Messina, together with the Russian zoologist Nikolaus Miclucho-Maclay (1846-1888), and the discussion escalated to building a whole network of biological stations (Groeben, 2006). Maclay (shown with Haeckel in Fig. 4) went on to establish a zoological station in Sydney, Australia (1881), while Anton Dohrn's dream of establishing a biological station did not have to wait as long. Anton Dohrn states in a letter to Charles Darwin (reported in Groeben, 2006, p. 294):

... I have found how difficult it is to study Embryology without an Aquarium. This want has suggested to me the idea of not only founding Aquariums, but also Zoological Stations or Laboratories in different parts of our European coasts.

His name was soon to be associated with the world's most famous biological station, that of Naples.

\section{The Stazione Zoologica di Napoli}

Anton Dohrn established the zoological station in Naples in 1872, making it thus one of the first such stations in the world. The city, which used to be the capital of the Kingdom of the Two Sicilies (until 1861), was therefore rich in culture and art and one of the largest cities in Europe, with ten times more inhabitants than Rome (Groeben, 2006). The local Naples administration provided, free of charge, a prime site on the waterfront, on the condition that Dohrn would fund the building itself. The idea was for the station to be financially independent (i.e. not connected to a university) and open to top-level international students and scientists. Financial independence was reached by a combination of the income provided through the admission fees to the adjoining Aquarium (an idea Dohrn had during a visit to the Berlin Aquarium) and, most importantly, an innovative measure introduced by Dohrn to finance his project: the rental of work and research space ('Bench/Table system'). This funding method required payment of an annual fee, entitling the contract partner (universities, governments, scientific institutions, private foundations, even individuals) to a workplace for one scientist, including access to all necessary equipment, technical expertise, marine organisms and literature to conduct research for one year (Fantini, 2000). Most importantly, investigators were completely free to pursue their own projects and ideas. Another asset of the Naples station was the detached laboratory in Ischia (today used for benthic ecology studies), allowing direct access to fresh marine plankton samples. The focus of the station on the study of marine organisms, the Aquarium, and the tradition of international collaboration are still in existence to this day, along with world-leading research in the field of molecular biology and genetics. For a more learned and in-depth documentation of the history of the Stazione Zoologica di Napoli and the early ideas of Anton Dohrn on biological stations, the reader is referred to the excellent works by Groeben (2006) and Fantini (2000).

\section{PAOLO ENRIQUES AND THE ZOOLOGICAL STATION IN NAPLES}

In addition to Haeckel, Dohrn, genetics and marine biological research, another link between the Stazione Zoologica di Napoli and radiolarians is represented by Paolo Enriques. Born in Leghorn from a family of Jewish descent in 1878, he studied at the universities in Florence, Rome and Bologna. He graduated in medicine in Göttingen, and added a PhD in Natural Sciences at the University of Bologna in 1901. He was Professor of Zoology, Comparative Anatomy and Physiology at the universities of Sassari (from 1911) and Padua (from 1921). Enriques published very important studies on genetics and inheritance, illustrating the links between them and evolution and enunciating the law of the independence of variability. His main works are: 'The cellular theory' (Enriques, 1911) and 'Mendel's Laws and Chromosomes' (Enriques, 1932). In his obituary in Nature ('F.A.B.', 1933, p. 265) he is described as 'the leader of Italian zoologists along the lines of genetic, physiological, and philosophical research'.

\section{Paolo Enriques and radiolarians}

In the 1912-1917 period, Paolo Enriques carried out his first research on radiolarians from plankton material at the Marine Biology Institute in Messina, resulting in two papers on colonial forms. From 1927 on, he regularly visited the Stazione Zoologica 


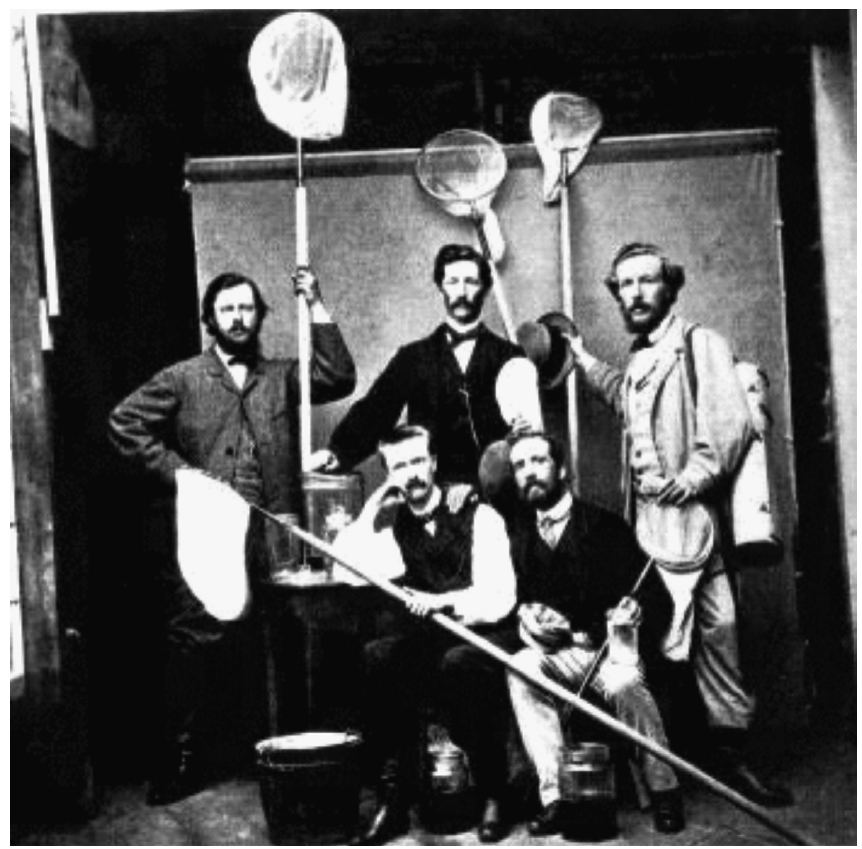

Fig. 3. Anton Dohrn, Richard Greeff, Ernst Haeckel (standing, left to right), Matthijs Salverda, Pietro Marchi (seated, left to right) on Helgoland, September 1865. Picture from Zissler (1995), original at the Ernst-Haeckel-Haus in Jena.

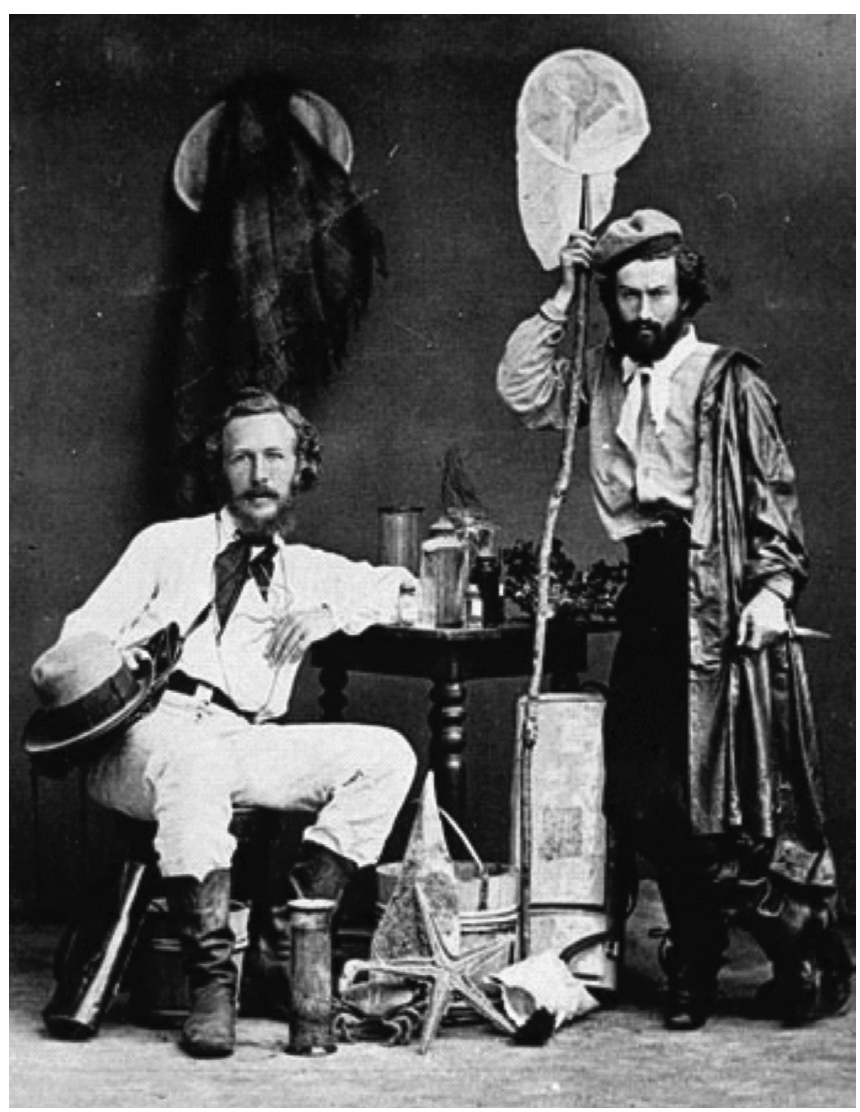

Fig. 4. Ernst Haeckel (seated left) and Nikolaus Miclucho-Maclay on Lanzarote, Canary Islands, 1866. Picture from Zissler (1995), original at the Ernst-Haeckel-Haus in Jena. in Naples, where he started to compile a monograph on radiolarians (Spumellaria, Nassellaria, Phaeodaria). Colosi (1933) reports how Enriques would devote several months' hard work a year collecting facts and observations contributing to his monograph. Unfortunately, his death in a car accident near Rome in December 1932 left this work unfinished. In his unpublished radiolarian classification he criticizes and emends the then existing radiolarian taxonomy, by applying ontogenetic and phylogenetic considerations to the reconstruction of relationships between taxa. His work continues the tradition mentioned above of zoologists and embryologists applying their knowledge from those disciplines to the study of evolutionary processes in microorganisms. Enriques' is one of the first attempts (if not the first one) to produce a 'natural' classification of radiolarians, i.e. based on available biological information on the taxa, and the known genetic/evolutionary relationships between them, instead of the formal classification schemes existing at his time. In fact, Haeckel's radiolarian classification was based on geometrical features of the shell and was, therefore, largely artificial. While this hampered the development of a more rigorous, and natural, classification system, Haeckel's scheme provided a relatively simple and intuitive way to classify this microfossil group. A natural classification scheme of radiolarians still does not yet exist.

An example of how Enriques' ontogenetic approach may have helped to clarify (still relevant!) taxonomic issues in radiolarians is represented by his remark about the species Actinomma trinacria and Actinomma boreale, where he agrees with Jørgensen (1905) and suggests that these taxa should be kept separate, and to ignore Schröder's (1909) opinion:

According to Schröder, this species (Actinomma trinacria) could also be a juvenile stage of Cromyechinus borealis Cleve, with the fourth shell not yet formed. But Jørgensen had already observed, in 1905, that $C$. borealis specimens are usually recognized by the transverse processes on the main spines. These processes indicate the future shell. Generally speaking, the formation of the more external shells is already sketched when the structure of the skeleton is thin, minute, juvenile. If one observes a strong, well developed, thick external shell, it is not likely that other shells will be formed. This formation law seems to be evident to me after having observed the different families and genera. It makes the taxonomist's task easier, since it will remove doubts as those advanced by Schröder (Enriques unpublished manuscript, translated from the original Italian by the present author).

\section{A view into Enriques' manuscript and his position on Haeckel's scheme}

Georges Merinfeld, a plankton specialist, visited the Zoological Station in Naples and, in a letter to the station dated February 2 1965, he wrote:

The material contained in this folder deals with two of the three groups of radiolarians: the Polycystina (= Radiolaria s.s.) and the Phaeodaria (the third group, Acantharia, has already been the object of Schewiakoff's monograph in 1926 . 
Total Number of species described by author (1867-1959)

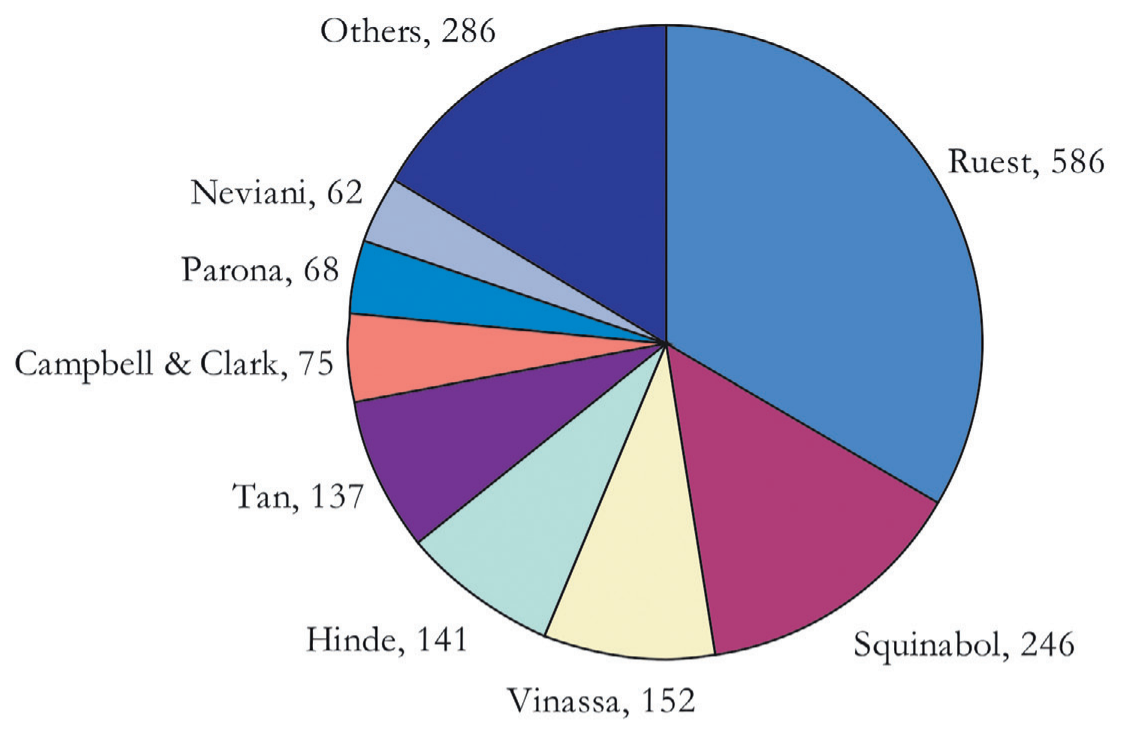

\section{Percentage contribution (by Ruest, italian authors, others)}

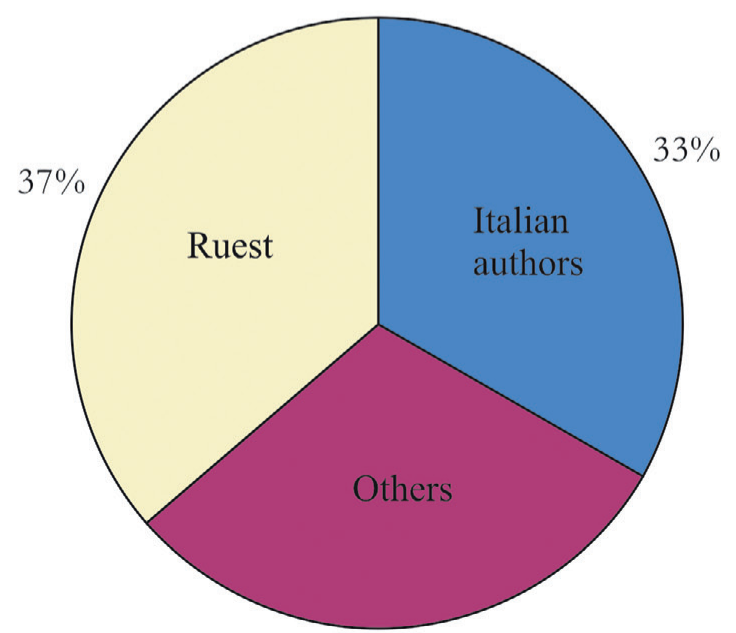

$30 \%$

Fig. 5. New Mesozoic radiolarian species described 1867-1959 (data from O’Dogherty et al., 2009). Squinabol and Vinassa rank second and third (after Rüst) in terms of total number of described species. Including the taxa described by Parona and Neviani, these four Italian authors together account for roughly one third of the species described over this time period.

His classification scheme will hardly need any modifications, even after electronic microscopy research). Both the drawings and the slides on which they are based are of a certain value for the description and the taxonomy of species belonging to the same genus, since many drawings have been completed with all possible attention to show the details in the skeletal structure in these species.
The following are excerpts from Enriques' manuscript, translated from the original Italian by the present author, which sketch some aspects of his approach to update Haeckel's scheme.

In general the intricate relationships between different radiolarians push the researchers towards acceptance of Haeckel's 

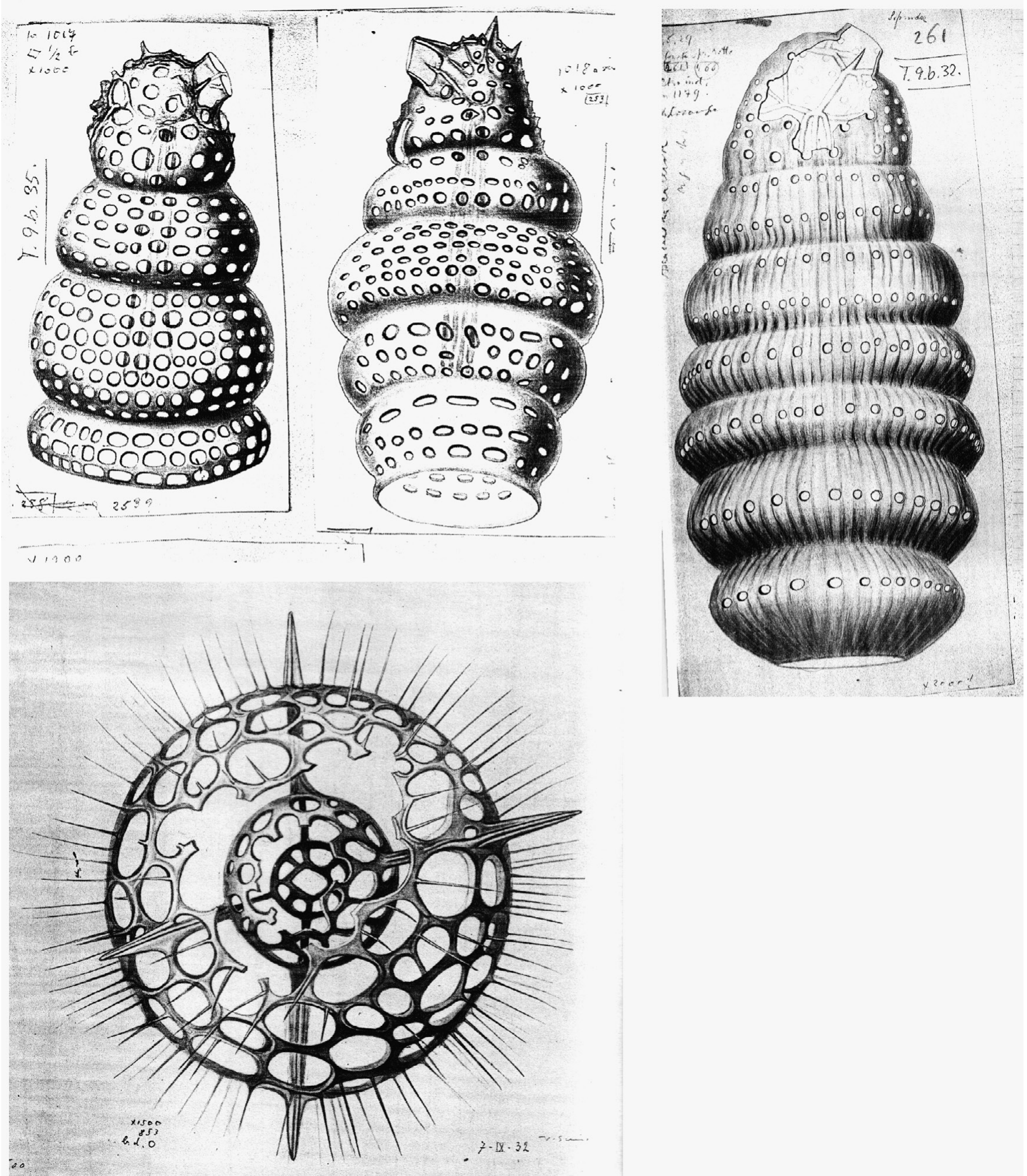

Fig. 6. Drawings of radiolarian species that Enriques intended to include in his manuscript on a classification of radiolarians, based on studies he was carrying out at the Stazione Zoologica 'Anton Dohrn' in Naples. Image: Christiane Groeben, Historical Archives of the Zoological Station Naples.

classification when they study this or that family, delaying to the future the construction of a new classification. Since we wanted to go away from Haeckel's tradition, and we hoped that shuffling was useful for re-ordering families in their natural relationships, the question rises if it is possible to find groups having definite architecture. 
Italy-based radiolarists of the nineteenth and twentieth centuries
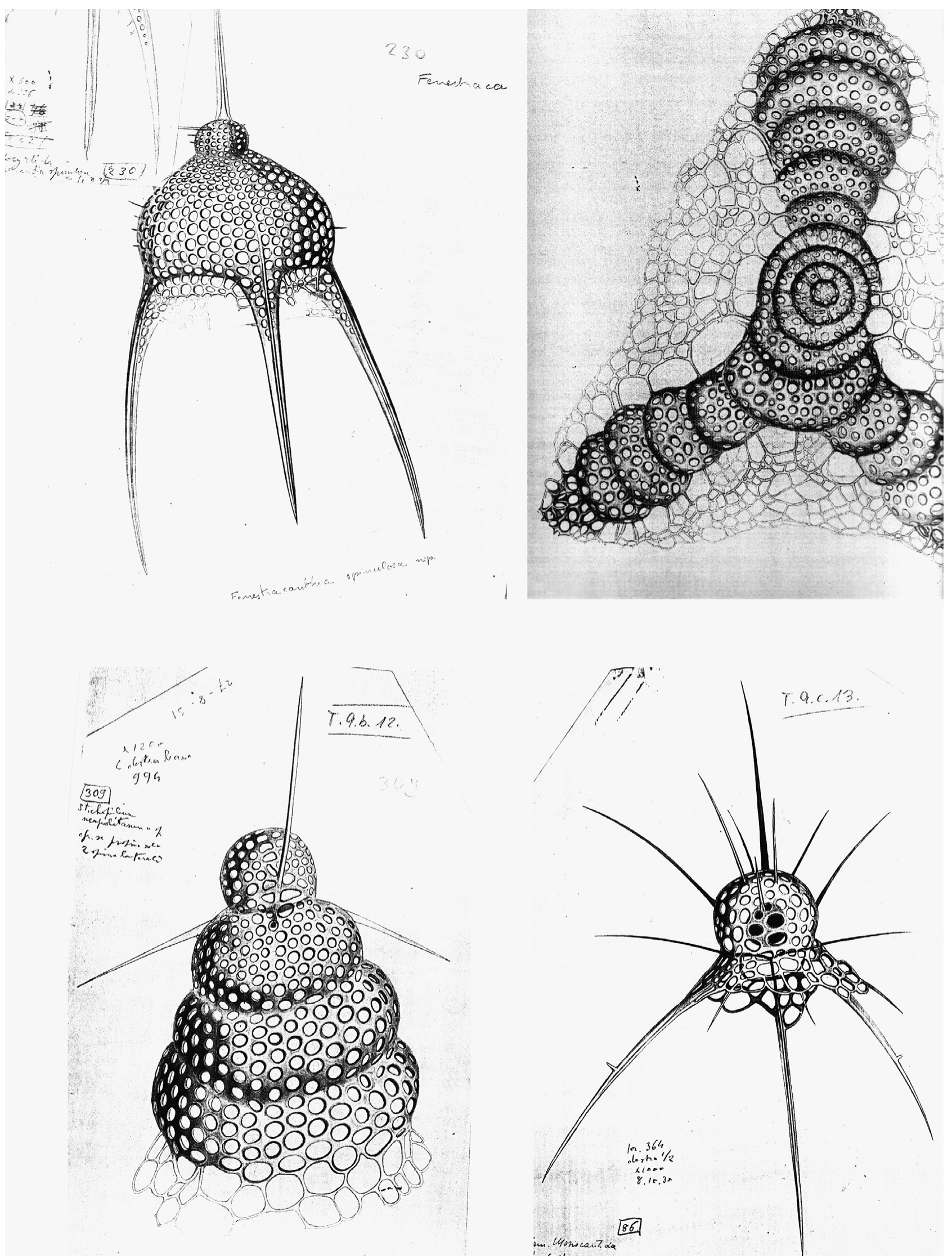

Fig. 7. Drawings of radiolarian species that Enriques intended to include in his manuscript on a classification of radiolarians, based on studies he was carrying out at the Stazione Zoologica 'Anton Dohrn' in Naples. Image: Christiane Groeben, Historical Archives of the Zoological Station Naples. 
Even if I do not have the possibility to directly examine all species by Haeckel, this is not a good reason to keep on using a wrong classification scheme. On the contrary I hope that once the basis of the classification scheme will be laid according to building plans and to embryonic development, the researchers will have a motivation to study the structural features, every time they will face a new or not well known species.

Already Haeckel held in consideration symmetry, but in a totally formal way. He divided Sphaeroidea in Lyosphaerida - without spines, Stylosphaerida - with two opposing spines, Cubosphaerida - with six spines, Astrosphaerida - with more than six spines. These groups are not corresponding at all to natural groups in shape or evolution. First of all, their order itself demonstrates the formalism of the classification: none, two, four, six, more than six spines. Does a radiolarian evolve from a spherical, spineless form, acquiring first two, then four, then six, then more spines? According to what we know, we may suppose it does not. We can observe infinite steps between the spherical, spineless form and the spherical form with many spines. In any group we may say that the spines may be added in an indefinite number. Evolution has probably, only as a secondary aspect, limited and defined the number of spines, reducing the indefinite central symmetry to a central symmetry with a defined, small, number of axes.

As I have said in the general part, there are no monophyletic systematic groups in Radiolaria. It is impossible to classify them according to a natural classification scheme according to the concepts of the Darwinian epoch, because such a natural classification scheme does not exist.

\section{THE LEGACY OF EARLY ITALIAN RADIOLARISTS}

Papers dealing with Mesozoic radiolarians appeared in the latter part of the nineteenth century, and the study of Mediterranean Mesozoic radiolarians began with Pantanelli (1880), who first described some species from Tuscany. He also applied radiolarians as tools to determine the age of Mesozoic terranes, thus becoming the second researcher to do so, after Zittel in 1876. This information is very important for reconstructing the history of complexly folded, faulted and accreted terranes. Obvious examples include a plethora of mountain chains and Mesozoic rock formations across Europe and Asia, related to the same orogenic events that generated the Italian Alps and Apennines, as well as a series of terranes accreted in island-arc settings (such as the Japanese Arc). These applications of radiolarians are still very important, and many of the modern 'radiolarists schools' (e.g. in Switzerland, Italy, Japan, USA etc.) have developed around the study of such scientific problems. Soon after Pantanelli's studies, Rüst (1885, 1889) and Parona (1890) described and illustrated numerous Cretaceous species from different Alpine locations in Italy, Switzerland and Austria.

In terms of sheer numbers of new Mesozoic radiolarian species described over the time interval 1867-1959 (O'Dogherty et al., 2009), Squinabol and Vinassa ranked second and third (after Rüst). If we add to their total the new species described by Parona (1890) and Neviani (1900), the general situation over this time interval was: (1) Rüst, (2) Italian authors, (3) others (with each accounting for c. $33 \%$ of the total; Fig. 5). However, even the truly remarkable 'score' of 586 new Mesozoic species described by Rüst was dwarfed by the $c$. five times higher number of living and fossil radiolarian species described in Haeckel (1887).

The taxa established by early Italian workers are, generally speaking, still commonly used in modern studies. As a qualitative example of this, a recent overview of Mesozoic radiolarian taxonomy (O’Dogherty, 2009) lists a high number of species and genera originally described by Squinabol, Parona and Pantanelli. As the author of the present paper is not a Mesozoic radiolarian specialist, the reader is referred to the above publication (and to O'Dogherty et al., 2009) for more details and statistics on taxa validity in studies dealing with Mesozoic radiolarians. Working concepts for most Mesozoic radiolarian species have been extensively examined and reviewed in connection with a taxonomic atlas of the Tethys (Baumgartner et al., 1995). To my knowledge, however, no extensive critical re-examination of type species and material originally described by early Italian authors has ever been carried out.

Enriques' taxonomic influence deserves special and separate mention, as this author died (1932) before completing a new classification scheme for radiolarians that he had set out to prepare while at the Zoological Station of Naples. As this work is as yet unpublished, any new species described in it are not formally valid. All that is left is a translation of his manuscript into English, and many excellently crafted drawings (a few examples are shown in Figs 6-7).

\section{ACKNOWLEDGEMENTS}

I wish to acknowledge the help of several people who strongly influenced the content of these pages: Christiane Groeben (Coordinator, History of Science Unit of the Zoological Station 'Anton Dohrn', Naples); Kjell Bjørklund (Palaeontological Museum, Oslo) for 15 years of friendship and radiolarian fun; David Lazarus (Museum für Naturkunde, Berlin) for inviting me to contribute to this thematic set of papers and checking a preliminary version of this paper. This research was funded by the New Zealand Foundation for Research, Science and Technology through GNS Science's 'Global Change Through Time Programme'.

\section{Manuscript received 22 November 2012} Manuscript accepted 22 November 2012

Scientific editing by F. John Gregory

\section{REFERENCES}

Baumgartner, P.O., O’Dogherty, L., Gorican, S., Urquhart, E., Pillevuit, A. \& De Wever, P. 1995. Middle Jurassic to Lower Cretaceous Radiolaria of Tethys: Occurrences, Systematics, Biochronology. Mémoires Géologiques (Lausanne), 23: 1-1162.

Colosi, G. 1933. Paolo Enriques. Italian Journal of Zoology, 4: 37-40.

Darwin, C. 1859. On the Origin of Species by Means of Natural Selection, or the Preservation of Favoured Races in the Struggle for Life. John Murray, London, 502pp.

Enriques, P. 1911. La teoria cellulare. Zanichelli, Bologna, xiv+496pp.

Enriques, P. 1932. Le leggi di Mendel e I cromosomi. Zanichelli, Bologna, 226pp.

'F.A.B.' 1933. Obituary, Prof. Paolo Enriques. Nature, 131: 265-266, http://dx.doi.org/10.1038/131265a0 
Fantini, B. 2000. The history of the Stazione Zoologica Anton Dohrn: An Outline. In Stazione Zoologica Anton Dohrn. Activity Report 1998/1999, Naples, ImPrint, 71-107.

Groeben, C. 2006. The Stazione Zoologica Anton Dohrn as a place for the circulation of scientific ideas: vision and management. In Anderson, K.L. \& Thiery, C. (Eds), Information for Responsible Fisheries: Libraries as Mediators. Proceedings of the 31st Annual Conference, Rome (Italy), October 10-14, 2005. International Association of Aquatic and Marine Science Libraries and Information Centers. Fort Pierce, FL (USA), 291-299.

Haeckel, E. 1860. Über neue, lebende Radiolarien des Mittelmeeres. Monatsberichte der Königlich Preußischen Akademie der Wissenschaften zu Berlin, 1861: 794-845.

Haeckel, E. 1881. Entwurf eines Radiolarien-Systems auf Grund von Studien der Challenger-Radiolarien [Basis for a radiolarian classification from the study of Radiolaria of the Challenger collection]. Jenaische Zeitschrift für Naturwissenschaft, 15: 418-472.

Haeckel, E. 1887. Report on the Radiolaria collected by H.M.S. Challenger during the years 1873-1876. Report on the Scientific Results of the Voyage of the H.M.S. Challenger, Zoology, 18: clxxxviii + 1-1803.

Jørgensen, E.H. 1905. The Protist plankton and the diatoms in bottom samples. VII. Radiolaria. In Nordgaard, O. (Ed.) Hydrographical and Biological investigations in Norwegian Fjords. Bergens Museum Skrifter, Ser. 1, 7: 114-142.

Lazarus, D. 2014. The legacy of early radiolarian taxonomists, with a focus on the species published by early German workers. Journal of Micropalaeontology, 33, 3-19.

Marsili, L.F. 1725. Histoire physique de la mer. Aux dépens de la Compagnie, Amsterdam, 173pp.

Neviani, A. 1900. Supplemento alla fauna a Radiolari delle rocce mesozoiche del Bolognese. Bollettino della Societa Geologica Italiana, 19: 645-671.

O’Dogherty, L. 2009. Inventory of Mesozoic radiolarian species (18672008). Geodiversitas, 31: 371-481.

O’Dogherty, L., De Wever, P. \& Goričan, Š 2009. Historical perspective: 140 years of Mesozoic radiolarian taxonomy. Geodiversitas, 31: $357-369$.
Pantanelli, D. 1880. I diaspri della Toscana e i loro fossili. Atti della reale Accademia nazionale dei Lincei, Memorie della Classe di Scienze fisiche, matematiche e naturali, 8: 35-66.

Parona, C.F. 1890. Radiolarie nei noduli selciosi del calcare giurese di Cittiglio presso Laverno. Bollettino della Societa Geologica italiana, 9: 132-175.

Rüst, D. 1885. Beitrage zur Kenntniss der fossilen Radiolarien aus Gesteinen des Jura. Paläontographica, 31: 269-321.

Rüst, D. 1889. Beitrage zur Kenntniss der fossilen Radiolarien aus Gesteinen des Kreide. Paläontographica, 34: 181-213.

Schröder, O. 1909. Die nordischen Spumellarien. II. Unterlegion Sphaerellarien. Nordisches Plankton, 7: 1-66.

Squinabol, S. 1903. Le Radiolarie dei noduli selciosi nella Scaglia degli Euganei. Contribuzione I. Rivista Italiana di Paleontologia, 9: $105-151$.

Squinabol, S. 1904. Radiolarie cretacee degli Euganei. Atti e Memorie della reale Accademia di Scienze, Lettere ed Arti in Padova, nuova serie, 20: 171-244.

Squinabol, S. 1912. Radiolari della strada nazionale al Monginevro. Bollettino del reale Comitato Geologico d'Italia, 43: 281-289.

Squinabol, S. 1914. Contributo alla conoscenza dei Radiolarii fossili del Veneto. Appendice - Di un genere di Radiolari caratteristico del Secondario. Memorie dell'Istituto geologico della Reale Università di Padova, 2: 249-306.

Vinassa de Regny, P.E. 1899. I radiolari delle ftaniti titoniane di Carpena (Spezia). Paleontographia Italica, 4: 217-238.

Vinassa de Regny, P.E. 1900. Rocce e fossili dei dintorni di Grizzana e di Lagaro nel Bolognese. Bollettino della Società Geologica italiana, 19: 321-348.

Vinassa de Regny, P.E. 1901. Radiolari Cretacei dell'Isola di Karpathos. Memorie della Reale Accademia delle Scienze dell'Istituto di Bologna, 9: 497-512.

Vinassa de Regny, P. 1955. Dante e il simbolismo pitagorico. Fratelli Melita, La Spezia (Italy), reprinted 1988.

Zissler, D. 1995. Five scientists on excursion - a picture of marine biology on Helgoland before 1892. Helgoländer Meeresuntersuchungen, 49: 103-112. 
